УДК 597.553.2.591.134

doi: $10.31140 / j . v e s t n i k i b .2019 .4(211) .4$

\title{
СОВРЕМЕННОЕ СОСТОЯНИЕ И ДИНАМИКА ПОПУЛЯЦИОННЫХ ПОКАЗАТЕЛЕЙ ЕВРОПЕЙСКОГО ХАРИУСА ТИМАНСКОГО ВОДОТОКА В УСЛОВИЯХ НЕРЕГУЛИРУЕМОГО РЫБОЛОВСТВА
}

\author{
Э.И. Бознак, А.Б. Захаров \\ Институт биологии Коми научного центра Уральского отделения Российской академии наук, Сыктывкар \\ E-mail: boznak@ib.komisc.ru
}

\begin{abstract}
Аннотация. Проанализировано изменение основных популяционных показателей европейского хариуса одного из водотоков Среднего Тимана (р. Вымь, бассейн р. Северной Двины). Зарегистрировано устойчивое уменьшение длины и массы тела рыб, входящих в контрольные уловы, сокращение количества возрастных классов, снижение среднего возраста, модального возрастного класса и суммарной доли неоднократно нерестящихся особей. На фоне сокращения численности происходит ускорение полового созревания рыб. В то же время хариус р. Выми характеризуется быстрым ростом. Причиной неблагополучного состояния верхневымской группировки хариуса является не техногенное нарушение среды обитания, а длительная чрезмерная эксплуатация рыбных ресурсов.
\end{abstract}

Ключевые слова: европейский хариус, размеры, возрастная структура, половое созревание, некоммерческое рыболовство, перелов

\section{Введение}

К числу уникальных природных богатств Республики Коми относятся водотоки, истоки которых расположены в центральной части Тиманского кряжа. Геоморфологические и экологические условия этих рек во многом определяют видовой состав и структуру их рыбного населения, основу которого составляют такие холодолюбивые оксифильные виды лососеобразных, как обыкновенный сиг и европейский хариус. В большинство средних и крупных тиманских рек заходит на нерест атлантический лосось (Захаров, 2019).

Хозяйственное освоение территории Тимана, связанное с разведкой и добычей минеральных полезных ископаемых, неизбежно приводит к возрастанию антропогенной нагрузки. Такое воздействие многопланово и включает как прямое нарушение водоемов и их водосборов в процессе разработки полезных ископаемых и строительства объектов инфраструктуры, так и возрастание пресса рыболовства. Последнее обусловлено развитием системы транспортных коммуникаций, облегчающей посещение рыболовами ранее труднодоступных участков водоемов. Вылов является одним из факторов, определяющих уровень смертности и скорость пополнения группировок хозяйственно ценных видов рыб. Под его влиянием изменяется не только структура популяции (пространственная, возрастная и половая), но и биологические особенности составляющих ее особей (скорость роста, скорость полового созревания и т.п.). В итоге интенсивный отлов может приводить к увеличению флуктуации биомассы (Fishing ..., 2006), снижению разнообразия и продуктивности, негативно сказываясь на устойчивости как отдельных популяций, так и рыбного населения водоема в целом (Old-Growth ..., 2017).

В верхнем течении р. Выми более 15 лет проводится комплексный мониторинг за состоянием гидробиоценозов, входящих в зону влияния
Среднетиманского бокситового рудника. Таким образом, этот водоток является прекрасной моделью для выявления изменений, происходящих в рыбном населении водотока в условиях, когда хозяйственное освоение водосбора напрямую не сказывается на состоянии среды обитания гидробионтов.

Действительно, несмотря на лесозаготовки (вторая половина XX в.) и промышленную разработку бокситового месторождения (с 1998 г.), заметные нарушения наблюдаются лишь на локальных участках русла р. Выми, непосредственно примыкающих к транспортным коммуникациям или объектам рудника. Гидрохимические и гидробиологические показатели отражают довольно стабильное и благополучное состояние данного водотока (Захаров, 2008).

Европейский хариус - Thymallus thymallus (Linnaeus, 1758) широко распространен в водоемах европейской части России. Он предпочитает водотоки полугорного типа и верховья крупных рек, часто заходит на нагул в олиготрофные озера (Атлас ..., 2002). Этот экологически пластичный, холодолюбивый и оксифильный вид характеризуется достаточно поздним половым созреванием $(4+\ldots 5+)$ и продолжительностью жизни до 15 лет (Сидоров, 2014). В водотоках Тимана хариус практически повсеместно является доминантом, составляя от 23.5 до $95.6 \%$ (в среднем около $70 \%$ ) в составе контрольных уловов (Захаров, 2011).

Цель работы - описать современное состояние и динамику основных популяционных показателей европейского хариуса верхнего течения р. Выми в условиях длительной иррациональной эксплуатации.

\section{Материал и методы исследования}

Работа выполнена на основе анализа материалов, собранных в период с 2002 по 2018 г. в ходе 
проведения мониторинга состояния рыбного населения верхнего течения р. Выми, осуществляемого специалистами Института биологии Коми НЦ УрО РАН при финансовой поддержке ООО «Боксит Тимана» (рис. 1).

Отлов рыбы проводили при помощи ставных жаберных сетей ячеей 20-40 мм. Все материалы (непрерывный ряд наблюдений с 2005 г.) собраны в близкие сроки (с 14-15 по 27-30 августа) с соблюдением единообразия методов сбора (конструкция и места постановки сетей, режим проверки и т.п.) и обработки материала.

У отловленных рыб измеряли длину тела по Смитту (AC - до конца средних лучей хвостового плавника) и общую массу тела $\left(\mathrm{P}_{1}\right)$. При вскрытии рыб отмечали пол и стадию зрелости гонад. Возраст рыб определяли по чешуе, собранной из первого-второго чешуйного ряда над боковой линией, позади от вертикали, проведенной от заднего края спинного плавника. Темп роста охарактеризован по результатам обратных расчислений с использованием формулы прямой пропорциональности Э. Леа (Правдин, 1966). Для уменьшения погрешности измерений обработка материалов проведена одним оператором. Для оценки относительной численности рыб рассчитывали индекс численности, т.е. число особей, отловленных в сеть длиной 30 м в течение 24 ч ее экспозиции (экз./30 м сети•сутки).

\section{Результаты и обсуждение}

На протяжении всего периода наблюдений хариус был доминирующим видом как в магистральном русле верхнего течения р. Выми, так и в ее притоках, используемых им для нереста и нагула. В зависимости от условий конкретного года доля вида в контрольных сетных уловах варьировала от 55 до 94 \% (рис. 2). При использовании крючковых орудий (спиннинг, поплавочная удочка, мушка и т.п.) уловы практически полностью могут состоять из европейского хариуса.

Размерно-возрастная структура. Размерно-весовые характеристики контрольных уловов хариуса на протяжении последних 12 лет наблюдений не оставались постоянными (табл. 1). В этот период межгодовые колебания длины тела не превышали 13 \%. Масса тела варьировала в более широких пределах (45\%). При этом размеры хариуса, отловленного в 2007-2018 гг., оказались заметно меньше по сравнению с данными конца 1990-х гг. (рис. 3). Так, средняя длина хариуса, выловленного в 2018 г., по сравнению с материалами 1998 г. сократилась в 1.4 раза, а масса тела - в 2.8 раза. Средний возраст хариуса по данным контрольных уловов 2018 г. оказался наименьшим за весь период наблюдений и составил 3.7 года (в 1998 г. этот показатель составил 6.6 лет).

Такое уменьшение размеров хариуса связано с постепенным сокращением в уловах доли рыб старших возрастных групп. Дей-

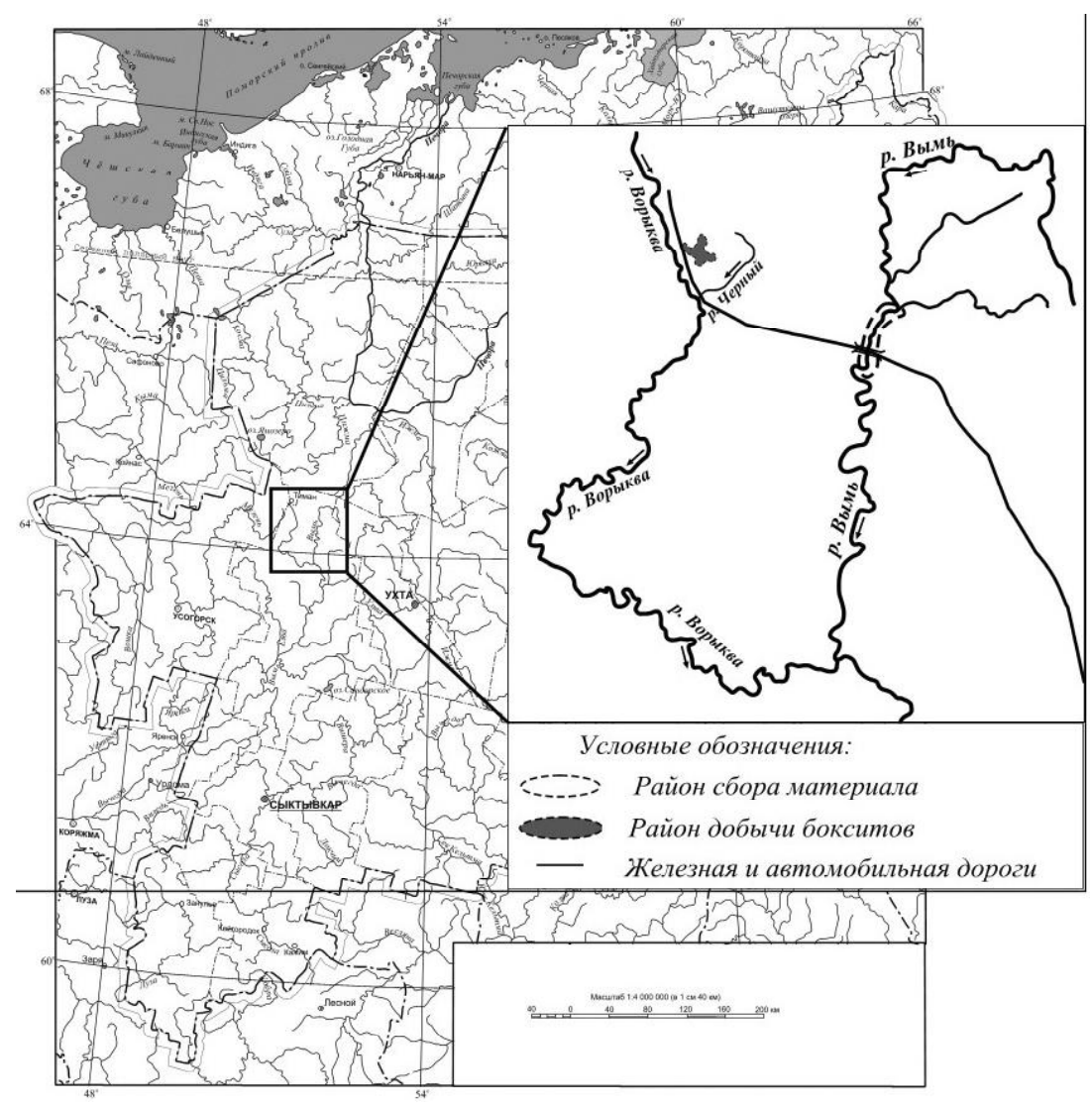

Рис.1. Карта-схема района сбора материала. ствительно, несмотря на межгодовые колебания, средняя доля особей, неоднократно принимавших участие в нересте (6+ и старше), снизилась с 33.5 (в 2002-2007 гг.) до $2.4 \%$ (в 2018 г.). При этом, если в уловах 2002-2009 гг. преобладали впервые и, реже, повторно созревающие особи (возраст 4+..5+), то с 2010 г. модальными группировками оказались возрастные классы 3+ или 4+ (неполовозрелые и впервые созревающие особи) (рис. 4). В сборах 2018 г. доминировали четырехлетние рыбы, причем суммарная доля неполовозрелых и впервые нерестующих особей $(3+\ldots 4+)$ составила практически $80 \%$.

Наблюдается и заметное сокращение возрастного ряда. Так, максимальный возраст хариуса, отловленного в 2010 и 2012 гг., составлял соответственно 9+ и $10+$ лет; в 2018 г. он не превышал 7+ (рис. 5). Таким образом, результаты анализа многолетних наблюдений в целом демонстрируют устойчивое 
омоложение группировки хариуса верхнего течения р. Выми.

Известно, что преобладание в уловах неполовозрелых и впервые нерестующих рыб характерно для популяций, структура которых нарушена в результате селективного вылова крупных половозрелых особей. При этом нарушается стабильность пополнения и остатка запасов рыб (Никольский, 1974), что может привести к снижению устойчивости популяции.

На сегодняшний день состояние кормовой базы рыб, обитающих в верхнем течении р. Выми, оценивается как близкое к естественному, заметных антропогенных нарушений данного участка водотока не выявлено (Захаров, 2008). Главной причиной изменения размерно-возрастных показателей рыб в уловах является, по-видимому, влияние интенсивного потребительского рыболовства.

Линейный и весовой рост. Хариус из русла верхнего течения Выми характеризуется быстрым линейным ростом, отставая по этому показателю лишь от рыб из некоторых водотоков бассейна р. Печоры (рис. 6). Результаты многолетних наблюдений демонстрируют скорее межгодовые колебания размерно-возрастных показателей рыб (табл. 2). Вероятно, их динамика обусловлена как межгодовой изменчивостью условий нагула, так и различиями в возрастном составе анализируемых выборок. В целом, быстрый рост свидетельствует о том, что условия нагула и состояние кормовой базы хариуса верхнего течения р. Выми длительное время остаются достаточно благоприятными.

Половая структура. Соотношение полов в группировке хариуса верхнего течения р. Выми на протяжении длительного времени остается близким к 1:1. Для значительного числа видов рыб такое значение соответствует нормальному соотношению полов (Никольский, 1974). Наблюдаемые колебания данного параметра в ту или иную сторону носят, по-видимому, случайный характер и незначительны по величине.

Половое созревание у вымского хариуса происходит в четырех-пятилетнем $(3+\ldots 4+)$ возрас-

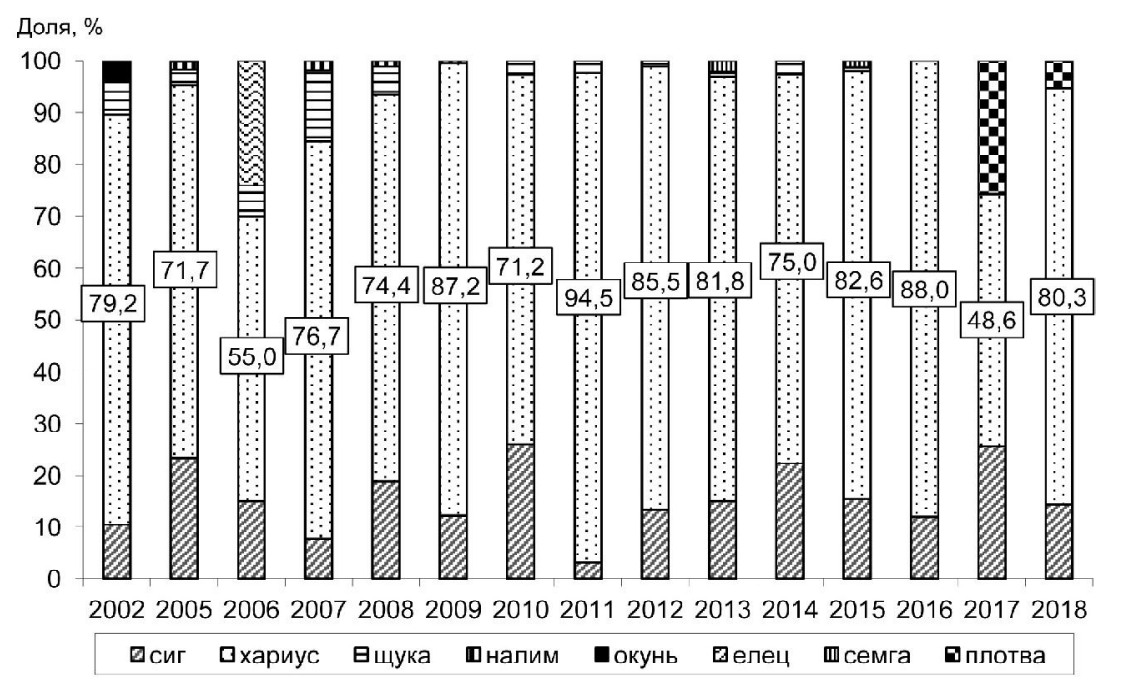

Рис. 2. Состав сетных уловов из верхнего течения р. Выми в летнеосенний период по данным разных лет.

Таблица 1

Размеры хариуса в сетных уловах из верхнего течения р. Выми

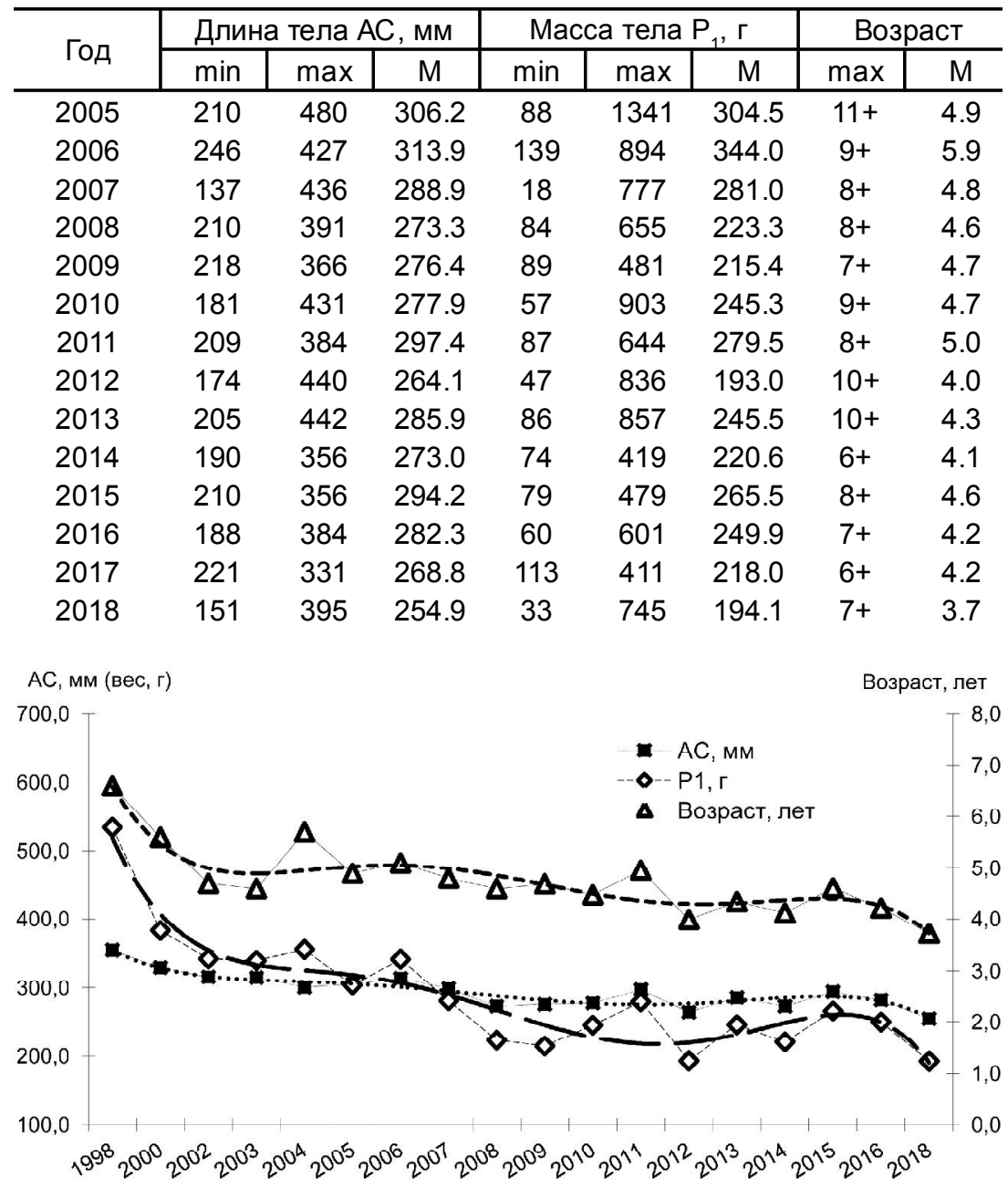

Рис. 3. Изменение размерно-весовых показателей и среднего возраста хариуса верхнего течения р. Выми по данным контрольных уловов.

те, что совпадает со временем наступления половозрелости хариуса в большинстве водотоков Вычегодского, Мезенского и Печорского бассейнов (Кучина, 1962; Остроумов, 1972). Однако, анализ накопленных данных демонстрирует посте- 
пенное ускорение полового созревания хариуса, обитающего в верхнем течении р. Выми. Если в конце 1990-х-начале 2000 гг. наиболее ранние случаи созревания отмечались у пятилетних (4+) рыб, то начиная с 2002 г. в контрольных уловах достаточно регулярно встречаются половозрелые четырехлетние $(3+)$ особи. Закономерно возрастает и доля созревших пятилетних рыб: в 2000 г. на пятом году жизни созревало 38 \% особей, а с 2013 г. их доля, как правило, превышала $70 \%$ (рис. 7).

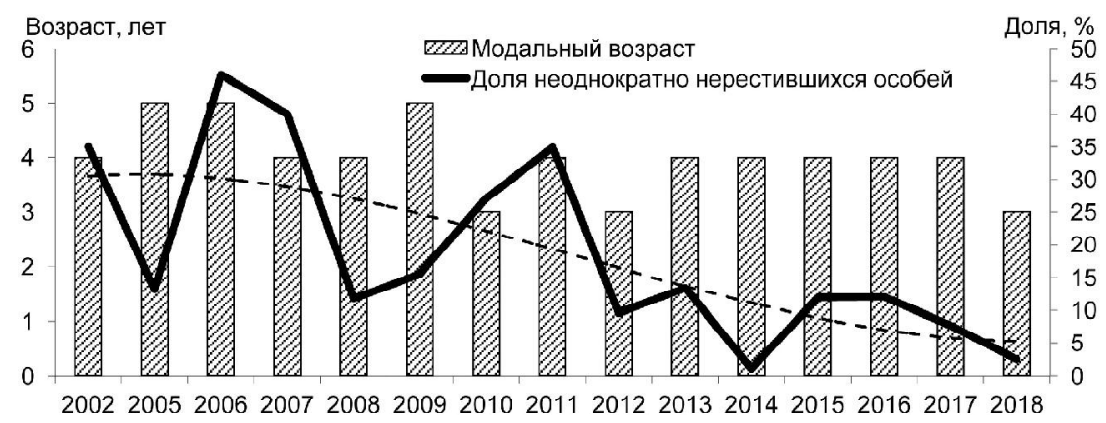

Рис. 4. Изменение модальной возрастной группы и суммарной доли неоднократно нерестившихся особей в контрольных уловах хариуса верхнего течения р. Выми.

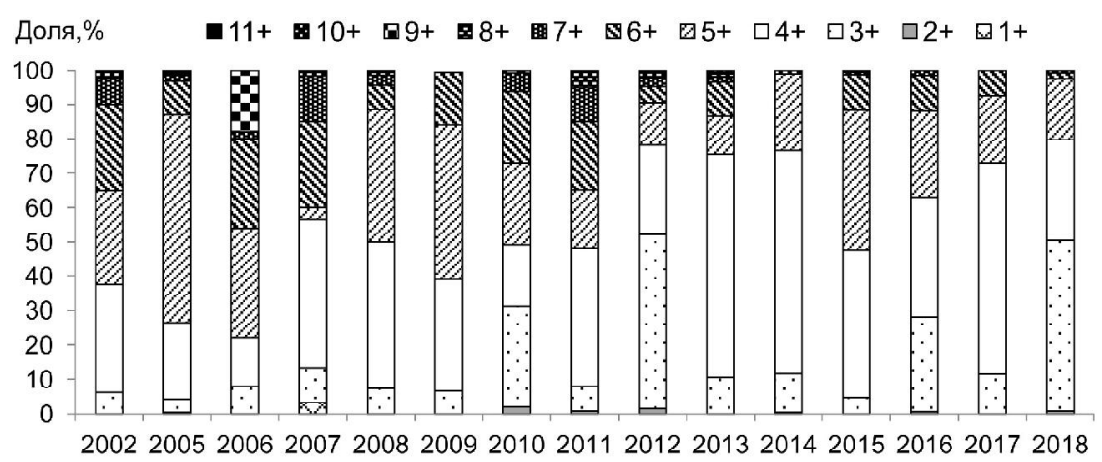

Рис. 5. Возрастная структура контрольных уловов хариуса из русла верхнего течения р. Выми в летне-осенний период 2002-2018 гг.

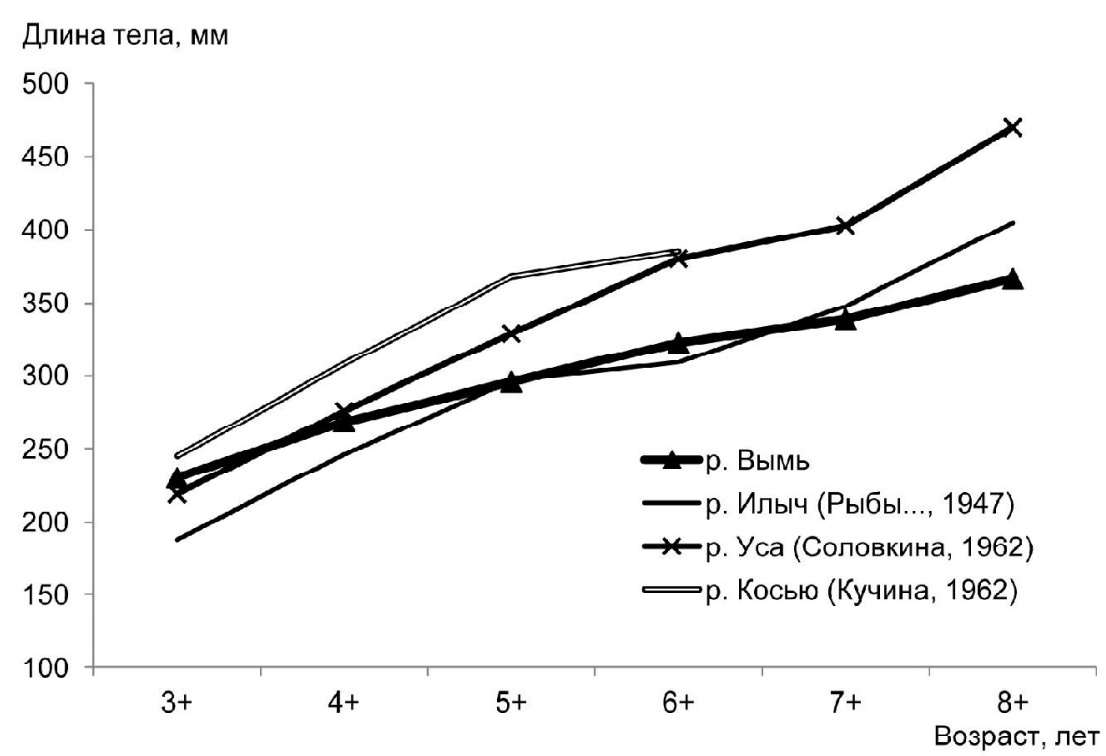
ков

Рис. 6. Линейный рост хариуса из р. Выми и некоторых других водото-
Известно, что интенсивный вылов, снижая плотность популяции, приводит к увеличению обеспеченности пищей, что в свою очередь вызывает ускорение роста и, как следствие, полового созревания рыб (Никольский, 1974; Котенев, 2009). Вылов может воздействовать на популяцию и как фактор отбора, предоставляющий себтивное преимущество быстро созревающим бам (Борисов, 1978; Fishing-induced ..., 2012). словиях интенсивного изъятия такие особи с большей вероятностью участвуют в размножении, обеспечивая воспроизводство популяции (Naish, 2008).

Действительно, ранее нами было отмечено ускорение роста хариуса в течение первых двух-трех лет жизни. Если учесть относительно стабильную кормовую базу хариуса в районе исследований и отсутствие выраженной корреляции между скоростью роста и среднегодовыми температурами (Захаров, 2014), то основной причиной ускорения полового созревания хариуса верхнего течения р. Выми следует признать воздействие практически не регулируемого рыболовства.

Относительная численность. Численность вида в верхнем течении р. Выми относительно высокая и на протяжении всего периода многократно превышает значения индекса, рассчитанные для других тиманских водотоков - p. Айювы (приток р. Ижмы) и верхнего течения р. Ворыквы (приток р. Выми), где группировки хариуса подорваны интенсивным рыболовством.

Наблюдаемые флуктуации численности в значительной степени зависят от климатических условий конкретного года, определяющих условия сбора материала. В годы с большим количеством осадков, выпадавших в весенне-летний период (2006 и 2017 гг.), и нехарактерно высоким уровнем воды наблюдали резкое снижение относительной численности, вызванное изменением пространственного распределения и активности хариуса на исследуемом участке русла р. Выми и снижением эффективности работы орудий лова (ставных сетей). Показательно, что после резкого снижения численность восстанавливается до обычного уровня уже на следующий год. Так, после резкого падения в 2006 г. в 2007- 
Средняя длина и масса тела разновозрастного хариуса, отловленного из верхнего течения р. Выми в 2000-2018 гг.

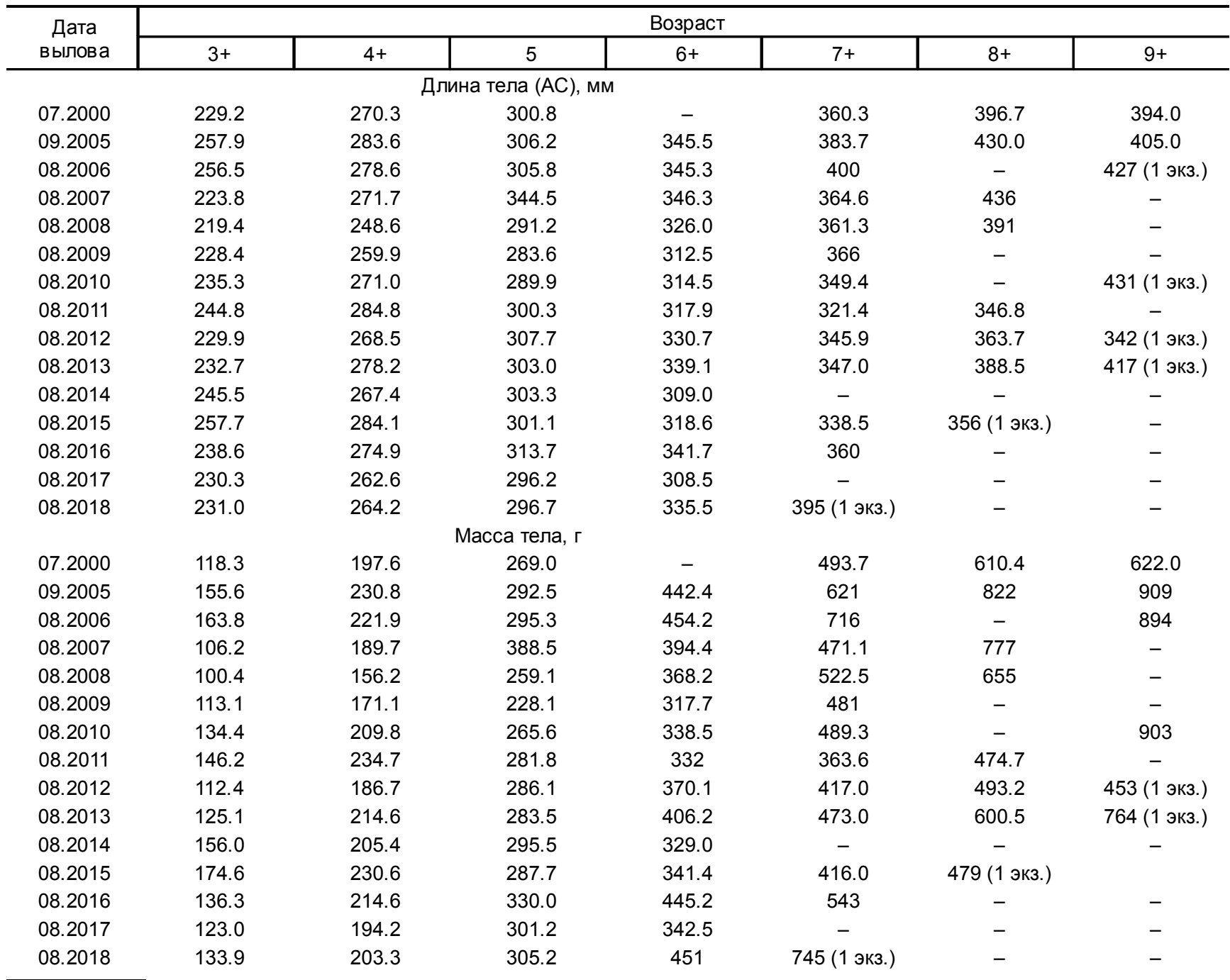

Примечание: прочерк - экземпляры в уловах отсутствовали.

2009 гг. отмечено повышение относительной численности хариуса, сменившееся в 2010 г. снижением этого показателя и его последующим ростом в 2011-2013 гг. и т.д. Имеющиеся данные позволяют говорить о чередовании подъемов и спадов численности хариуса, имеющих практически четырехлетний цикл (рис. 8).

Проведенный нами ранее анализ показал, что после резкого сокращения в 2005 г. популяция хариуса перешла в стационарное состояние с более низким уровнем численности (около 4.0 экз./сеть॰сутки), в котором она находилась по крайней мере до 2016 г. (Бознак, 2019). Возрастание относительной численности хариуса в 2018 г. не следует рассматривать в качестве обнадеживающего «сигнала». Как уже было отмечено, это повышение сопровождалось устойчивым сниже- нием размеров тела и омоложением рыб в контрольных уловах. Так, по сравнению с данными 2005 г. (величина индекса численности в этот период была незначительно выше современной), средняя длина тела хариуса уменьшилась в 1.2 раза, средняя масса - в 1.6 раза, а средний возраст сократился в 1.3 раза (от 4.9 до 3.7 лет).

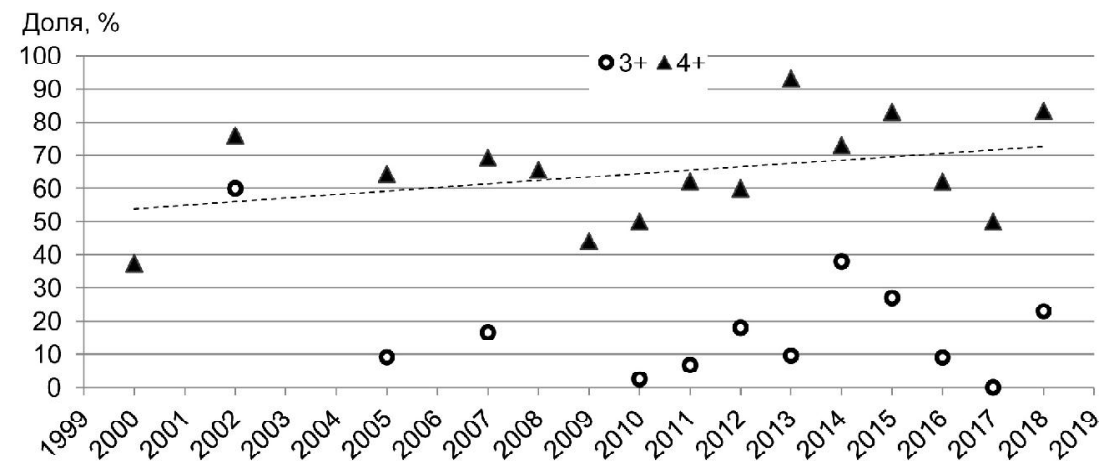

Рис. 7. Доля половозрелых особей в возрастных группах хариуса верхнего течения р. Выми (по данным разных лет). 


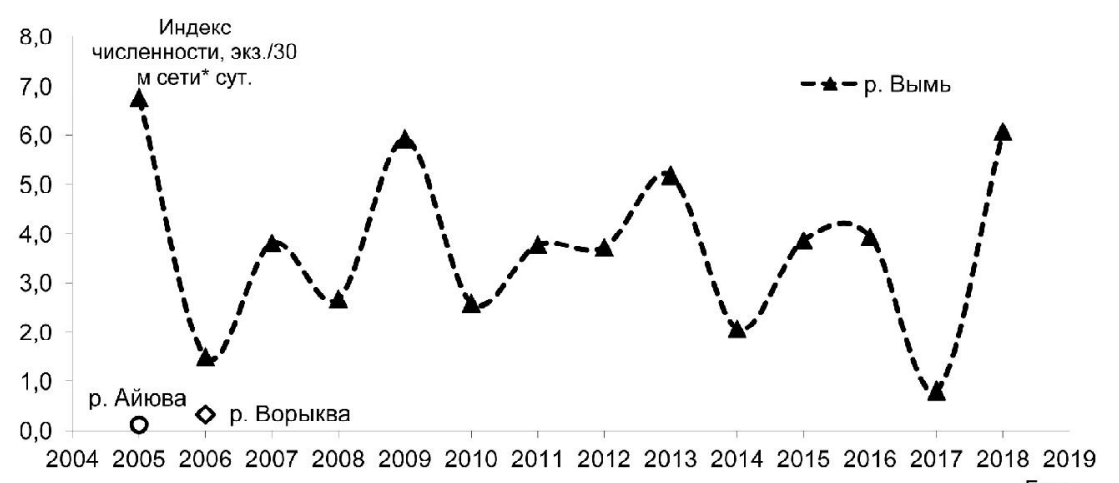

(0)

Рис. 8. Межгодовое изменение индексов численности хариуса верхнего течения р. Выми.

\section{Заключение}

Таким образом, группировка хариуса, обитающая на исследуемом участке верхнего течения р. Выми, в течение нескольких последних лет находится в состоянии, далеком от благополучного.

При отсутствии выраженного техногенного воздействия численность хариуса зависит от эффективности воспроизводства вида и уровня смертности (в том числе вылова). Условия воспроизводства хариуса в верхнем течении р. Выми можно считать достаточно благоприятными. Сколько-нибудь заметных техногенных нарушений нерестовых и нагульных участков в районе проведения мониторинга не наблюдается. Эффективность размножения рыб зависит от климатических условий конкретного года. По-видимому, основным фактором, лимитирующим численность популяций вида, является воздействие практически бесконтрольного вылова.

По наблюдениям авторов количество рыболовов в районе проведения работ за последнее время значительно возросло, одновременно расширился участок русла, подвергающийся облову. На исследуемом участке верхнего течения р. Выми (территория ихтиологического заказника «Вымский») только в последней декаде августа одновременно может находиться от четырех до восьми рыболовов, деятельность которых никак не контролируется.

Тем не менее, сохранение в естественном состоянии нерестилищ и мест нагула, а также быстрый рост хариуса позволяет прогнозировать восстановление его запасов. Этому будет способствовать реализация комплекса охранных мероприятий, таких как усиление охраны водных биологических ресурсов и введение полного запрета на лов рыбы в бассейне р. Выми сроком не менее чем на пять лет, рекомендованного Институтом биологии Коми НЦ УрО РАН еще в 2016 г.

Данная работа выполнена в ралках государственного задания "Распространение, систелатика и пространственная организаиия фауны и населения жи вотных таежных и тундровых ландшафтов и экоси- стем европейского северо-востока Росcuu» № AAAA-A17-117112850235-2.

\section{ЛИТЕРАТУРА}

Атлас пресноводных рыб России : в 2 т., Т. 1. / под ред. Ю. С. Решетникова. - Москва : Наука, 2002. - 379 с.

Бознак, Э. И. Влияние усиления интенсивности любительского лова на рыбное население водотока зоны хозяйственного освоения / Э. И. Бознак, А. Б. Захаров, В. Г. Терещенко // Биология внутренних вод. -2019 . - № 1. C. 56-64. - doi: 10.1134/S03209652 1901005

Борисов, В. М. Селекционное влияние промысла на структуру популяции длинноцикловых рыб / В. М. Борисов / Вопросы ихтиологии. - 1978. - Т. 18, вып. 3. C. $1010-1019$.

Захаров, А. Б. Современное состояние рыбного населения водотоков Тимана / А. Б. Захаров, Э. И. Бознак // Современное состояние биоресурсов внутренних водоемов : Материалы докладов I Всероссийской конференции с международным участием. - Москва : АКВАРОС, 2011. - С. 243-250.

Захаров, А. Б. Многолетняя динамика линейного роста европейского хариуса тиманского водотока (верхнее течение р. Выми) / А. Б. Захаров, Э. И. Бознак // Современное состояние биоресурсов внутренних вод : Материалы докладов II Всероссийской конференции с международным участием : 6-9 ноября 2014 г., Борок, Россия. - Москва : Полиграф-Плюс, 2014. C. $184-190$.

Захаров, А. Б. Рыбное население водотоков Тимана / А. Б. Захаров, Э. И. Бознак. - Сыктывкар, 2019. $184 \mathrm{c}$.

Захаров, А. Б. Ихтиофауна малых водотоков в районе разработки бокситовых месторождений Тимана / А. Б. Захаров, М. И. Черезова // Разнообразие и пространственно-экологическая организация животного населения европейского Северо-Востока. - Сыктывкар : Коми научный центр УрО РАН, 2008. - С. 54-80.

Котенев, Б. Н. Исследование возрастного состава и роста трески Gadus morhua Баренцева моря в связи с оценкой состояния ее запасов / Б. Н. Котенев, Е. Н. Кузнецова, М. В. Бондаренко // Вопросы ихтиологии. 2009. - T. 49, № 1. - C. 52-60. - doi: 10.1134/ S0032945209010068

Кучина, Е. С. Ихтиофауна притоков реки Усы / Е. С. Кучина // Рыбы бассейна реки Усы и их кормовые peсурсы. - Москва : Изд-во АН СССР, 1962. - С. 176211.

Рыбы бассейна верхней Печоры / Г. В. Никольский, Н. А. Громчевская, Г. И. Морозова, В. А. Пикулева. - Москва : Изд-во МОИП, 1947. - Т. 6 (21). C. 5-203.

Никольский, Г. В. Теория динамики стада рыб как биологическая основа рациональной эксплуатации и воспроизводства рыбных ресурсов / Г. В. Никольский. - Москва : Пищевая промышленность, 1974. 447 c.

Остроумов, Н. А. ЖЖивотный мир Коми АССР / Н. А. Остроумов. - Сыктывкар : Коми книжное издательство, 1972. - 280 с.

Правдин, И. Ф. Руководство по изучению рыб / В. Г. Правдин. - Москва : Пищевая промышленность, 1966. - 376 с.

Сидоров, Г. П. Лососеобразные рыбы водоемов европейского Северо-Востока / Г. П. Сидоров, Ю. С. Решетников. - Москва : Товарищество научных изданий КМК, 2014. - 346 с. 
Соловкина, Л. Н. Рыбы среднего и нижнего течения реки Усы / Л. Н. Соловкина // Рыбы бассейна реки Усы и их кормовые ресурсы. - Москва : Изд-во AH CCCP, 1962. - C. 88-135.

Fishing-induced evolution of growth: concepts, mechanisms and the empirical evidence / K. Enberg, C. Jorgensen, E. S. Dunlop, O. Varpe, D. S. Boukal, L. Baulier, S. Eliassen, M. Heino // Marine Ecology. - 2012. - N 33. P. 1-25. - doi: 10.1111/j.1439-0485.2011.00460.x

Fishing elevates variability in the abundance of exploited species / C. H. Hsieh, C. S. Reiss, J. R. Hunter,
J. R. Beddington, R. M. May, G. Sugihara // Nature. 2006. - N 443. - P. 859-862. - doi: 10.1038/nature 05232

Naish, K. A. Bridging the gap between the genotype and the phenotype: linking genetic variation, selection and adaptation in fishes / K. A. Naish, J. J. Hard // Fish and fisheries. - 2008. - N 9. - P. 396-422. - doi: 10.1111/j.1467-2979.2008.00302.x

Old-Growth Fishes Become Scarce under Fishing / L. A. K. Barnett, T. A. Branch, A. R. Ranasinghe, T. E. Essington // Current Biology. - 2017. - N 27. - P. 28432848. - doi: 10.1016/j.cub.2017.07.069

\title{
THE CURRENT STATE AND DYNAMICS OF POPULATION PARAMETERS OF THE EUROPEAN GRAYLING FROM THE TIMAN WATERCOURSE IN THE BAUXITE DEPOSIT DEVELOPMENT AREA
}

\author{
E.I. Boznak, A.B. Zakharov \\ Institute of Biology of Komi Scientific Centre of the Ural Branch of the Russian Academy of Sciences, Syktyvkar
}

Summary. The paper analyzes the changes in the main population indexes of the European grayling in one of the streams of Middle Timan (the Vym River, the North Dvina River basin) in the area affected by the Middle Timan bauxite deposit. Based on the analysis of the results of long-term observations, a number of signs have been noted that indicate a depressive state of the upper Vym group of grayling. We found a steady reduction in the length and body weight of fish in the control catches. From 2002 to 2018, the average body length of grayling reduced by almost $20 \%$, weight - by $43 \%$. A number of negative changes in the age structure are observed: a reduction in the number of age classes (from 6-9 in 2002-2005 to 4-6 in 2017-2018), and a decrease in the average age (from 4.7-5.7 to 3.7 full years of life). There is a change in the modal age class (from $4+\ldots 5+$ to $3+$ ) and the share of repeatedly spawning individuals (from $35 \%$ in 2002 to $2-8 \%$ in $2017-$ 2018). Against the background of a decrease in numbers, compared to the data from late 1990 s - early 2000 s, sexual maturation of fish is accelerated. At the same time, Vym grayling is characterized by rapid growth. The reason for the unfavorable state of the grayling in the upper reaches of the Vym River is not a technogenic disturbance of the fish habitat, but long-time overfishing of the species. Nevertheless, preservation in the natural state of spawning and feeding grounds, as well as the rapid growth of grayling, allows us to rely on the restoration of stocks in case of strengthening protection measures.

Key words: the European grayling, body size, age structure, sexual maturation, non-commercial fishing, overfishing 